\title{
The Implementation of Blended Learning Model on Motivation and Students' Learning Achievement
}

\author{
Zeinor Rahman ${ }^{1, a^{*}}$, Tri Rijanto ${ }^{1, b}$, Ismet Basuki1,, \& Meini Sondang Sumbawati ${ }^{1, d}$ \\ 1Department of Technology and Vocational Education, State University of Surabaya, East Java, Indonesia \\ a zeinor.18009@mhs.unesa.ac.id; b tririjanto@unesa.ac.id; c ismetbasuki@unesa.ac.id; d meinisondang@unesa.ac.id; \\ *Corresponding Author: zeinor.spd@gmail.com | Phone : +6287849460456
}

\begin{abstract}
This study aims to determine differences in students' motivation and learning achievement in KKPI subjects between students who use the face-to-face learning model and students who use blended learning models, increased motivation and student achievement in KKPI subjects due to the application of the blended model learning, and the interaction of the influence of the application of learning models and motivation on KKPI student learning achievement at SMK 1 Kamal Bangkalan. This quasi-experimental study uses two groups, namely the experimental group using the blended learning model and the control group using the face-to-face learning model. The study population was students of class XI SMKN 1 Kamal Bangkalan. The research sample consisted of 57 students divided into 30 students in the control group and 27 students in the experimental group. Data collection using questionnaires and multiple choice test questions. The results showed that there were significant differences between motivation and student achievement using the blended learning model and students using the face-to-face learning model, there was a significant increase in students' motivation and learning achievement due to the application of the blended learning model, and there was no interaction of influence the application of learning models and motivation to student learning achievement.
\end{abstract}

Keywords: blended learning; face-to-face learning; motivation; learning achievement

\section{Introduction}

The government encourages the concept of competency based education and encourages the growth of vocational education schools (SMK) through massive efforts by reversing the ratio of high school and vocational schools to 33:67 in 2015. Various strategic steps taken by the government began construction of vocational education facilities such as school buildings, equipment and practice materials to improve the quality of teachers through education and training programs and scholarships. Being a professional teacher is a necessity that must be realized. So many teachers are professional but do not have good pedagogical skills. Pedagogical abilities include the ability to organize learning that educates, utilizes information and communication technology for the benefit of learning and facilitates the development of the potential of students to actualize the various potentials they have (Fadilla et al, 2020). Therefore the need for the teacher's ability to combine various learning resources, the use of appropriate methods and mastery of the material is absolutely necessary.

According to the American Heritage Dictionary, learning is the process of gaining knowledge, understanding or mastery through experience or study (Hergenhahn and Olson, 2008; Chrisdian et al, 2020; Dachi \& Batubara, 2020; Nagara et al, 2020). If learning is the process of gaining knowledge, students should be encouraged to actively construct the knowledge they will get and try to find answers to the problems they encounter. While the teacher acts as a facilitator and motivator in learning. Through this role the teacher should actively develop concepts and methods of learning that are interactive and meaningful for students. However, most teachers still use conventional learning models such as face to face learning. Demands and civilization have experienced a shift from the analog world to the digital dimension through rapid advances in information technology. At the same time the teacher is challenged to combine traditional learning models and advances in information technology to balance diverse student learning styles. In general the use of ICT technology has flourished in various schools, especially vocational schools (Mugaya, 2020). The application of e-learning is one of the learning technology innovations that integrates information and communication technology with lesson content. According to Naidu (2006: 1) e-learning is an educational activity indi- 
vidually or in groups that are done online or offline via a network or personal computer and other electronic devices. This learning model is flexible which allows e-learning participants to access anytime and from anywhere. But learning is not merely based on technology because learning is essentially more on the process of interaction between teachers, students and learning resources. Although e-learning can be used independently by students, the existence of a teacher becomes very meaningful as an adult whose function is to provide support and assist students in the learning process (Plummer, 2012; Dorahman et al, 2020; Irfansyah et al, 2020; Jamaludin et al, 2020). In other words, the face-to-face process is important and should not be abandoned in learning. Therefore the learning model that combines (blending) the method of face to face learning with e-learning in an integrative and systematic way will make the learning process more meaningful.

This study aims to determine differences in motivation and students' learning achievement between learning with face-to-face learning model compared to blended learning model learning and increased motivation and students' learning achievement due to the influence of the application of learning models. In addition, the study also aimed to determine the effect of the interaction of learning models and motivation on improving student achievement in SMK 1 Kamal Bangkalan on KKPI subjects.

\section{Literature Review}

\subsection{Motivation to Learn}

The word motivation comes from the Latin word movere, which means move. Motivation can also be interpreted as an effort that can cause a person or group of people to be moved to do something because they want to achieve their desired goals or get satisfaction with their actions (Rahmi et al, 2020). According to Jex (2002: 210) motivations such as gravity that cannot be seen visually or felt but can only be seen the effects produced by it. In everyday life motivation has a very strategic role including the learning process.

According to Woolfolk (2004: 351) motivation is generally divided into two, namely: (1) intrinsic motivation, and (2) extrinsic motivation. Intrinsic motivation (intrinsic motivation), namely internal motivation to do something for the sake of something itself (the goal itself). While extrinsic motivation (extrinsic motivation), which is doing something to get something else (a way to achieve goals). Extrinsic motivation is often influenced by external incentives such as reward and punishment. Both of these factors must receive the most attention from a teacher, especially in an effort to improve student learning achievement. Achievement motivation according to Wade \& Tavris (2008: 459) emphasizes the goals and reasons a person has for pursuing these goals. Objectives function effectively to increase motivation by fulfilling the following 3 things: (1) goals must be specific, (2) goals must be challenging, but achievable, and (3) goals are limited to getting what they want, not avoiding what they don't want. Achievement motivation encourages a person to study hard in order to achieve the goals he has set. There are at least 6 indicators of student learning motivation (Sofyan and Uno, 2004: 24; Hutasuhut, 2019): (1) desire and desire to succeed, (2) encouragement and needs in learning, (3) hopes and ideals of the future, (4) appreciation in learning, (5) interesting activities in learning, and (6) a conducive learning environment.

\subsection{Learning Achievement}

The delivery of education in schools is done through the teaching and learning process. The implementation does not always go well, because there are often obstacles. These obstacles will be overcome if the teaching and learning process is carried out with discipline. The learning process that takes place at school refers to a curriculum that has been formulated by all competent parties. The curriculum contains a number of competency standards that must be met and become indicators of student learning achievement. According to Slavin (2009: 271) student achievement is measured to the extent that concepts or competencies that are learning objectives (instructional objectives) or behavioral objectives can be mastered by students at the end of the teaching period.

Students' learning achievement shows that he has experienced a learning process and has experienced changes both changes in having knowledge, skills, or attitudes (Puspitasari et al, 2020). Learning achievement can indicate the level of success of a person after doing the learning process in making changes and developments (Sjahrir et al, 2020; Siregar et al, 2020). This is because learning achievement is the result of an assessment of the abilities, abilities and specific skills that are learned during the learning period. Therefore Johnson (2009: 30) asserts that a teacher must prepare a series of tests aimed at summarizing student achievement including: (1) completeness in certain material in the curriculum, (2) cognitive abilities, and (3) student potential. Meanwhile according to Daryanto (2009: 51) there are several factors that affect the learning process of students, namely: (1) Internal Factors, including: physical condition, psychological condition and student fatigue. (2) External factors, including: family factors, school factors, community factors. 


\subsection{Blended Learning}

The use of information technology applications (e-learning) as a learning medium is increasingly being found in education. The concept of e-learning certainly gives a new nuance to the educational process which so far has only relied on the existence of the teacher. According to Clark \& Mayer (2008: 10) that e-learning is learning that is presented with the help of computers. The letter "e" in e-learning means that the material provided is digital so that it can be stored in an electronic device. E-learning illustrates that with the existence of information and communication technology, especially the internet, learning becomes more open (flexible) and flexible (flexible), happening anytime, anywhere and with anyone to any location (distributed), based the community. According to Castle and McGuire (2010: 36), e-learning can improve learning experiences because students can learn anywhere and in any condition as long as they are connected to the internet without having to follow face-to-face learning (face to face learning).

Blended learning is a flexible approach to designing programs that support a mixture of different times and places for learning. According to Rovai and Jordan (2004: 3) the blended learning model is basically a combination of learning excellence done face-to-face (face to face learning) and virtually (e-learning). Online learning or e-learning in blended learning becomes a natural extension of traditional classroom learning using face-to-face learning. Based on the proportion of content delivered online, Allen et al (2007: 5) provide a clear categorization of blended learning, traditional learning, web facilitated and online learning. From table 1 it can be seen that a learning is said to be in the form of blended or hybrid when the portion of elearning is in the range of $30-79 \%$ combined with face-to-face (face to face learning). On the other hand, the existence of a blended learning model encourages educators to change the educational paradigm from teacher-centered learning to student-centered learning. According to Carman (2005: 2), there are five keys to implementing learning by using blended learning, namely: (1) Live Event, direct learning or face-to-face synchronization in the same time and place or at the same time but different places. (2) Self-Paced Learning, which is combining with self-paced learning which allows participants to learn anytime, anywhere online. (3) Collaboration, combining collaboration, both teacher collaboration, and collaboration between learning participants. (4) Assessment, the designer must be able to formulate a combination of online and offline assessment types both test and non-test. (5) Performance Support Materials, ensure learning materials are prepared in digital form, accessible to study participants both offline and online.

Table 1. Proportion of Content Delivered Online

\begin{tabular}{cll}
\hline $\begin{array}{c}\text { Proportion of } \\
\text { contest delivered } \\
\text { online }\end{array}$ & Type of course & \multicolumn{1}{c}{ Typical description } \\
\hline $\begin{array}{c}0 \% \\
1 \text { to } 29 \%\end{array}$ & $\begin{array}{l}\text { Traditional } \\
\text { Web Facilitied }\end{array}$ & $\begin{array}{l}\text { Course with no online technology used content is delivered in writing or orally. } \\
\text { Course which uses web based technology to facilitate what is essentialy a face to face } \\
\text { course. Uses a course management system (CMS) or web pages to post the syllabus and } \\
\text { assignment, for example. } \\
\text { Course that blends online and face-to-face delivery. Substantial proportion of the } \\
\text { content is delivered online. Typically uses online discussion, and typically has some } \\
\text { face-to-face meetings. } \\
\text { A course where most or all of the content is delivered online. Typically have no face-to- } \\
\text { face meetings. }\end{array}$ \\
\hline $80+\%$ & Blended/Hybrid & Online
\end{tabular}

Source: Allen, E, Seaman, J \& Garrett, R. (2007). Blending in: The extent and promise of blended education in United States, Annual Report, Sloan Consortium.

\section{Methods}

\subsection{Explaining The Difference Between Training And Education}

This research is a quantitative research with a quasi-experimental design approach. The group used in the study amounted to 2 groups, namely the experimental group using face to face learning model and the control group using mixed model learning (blended learning).

Table 2. Nonequivalent Group Design

\begin{tabular}{cccc}
\hline Group & Pre-Test & Treatment & Post-test \\
\hline Experiment & $\mathrm{O}$ & $\mathrm{X}_{1}$ & $\mathrm{O}$ \\
Control & $\mathrm{O}$ & $\mathrm{X}_{2}$ & $\mathrm{O}$ \\
\hline
\end{tabular}

Explanation:

$\mathrm{O}$ : Provision of motivation questionnaires and written tests to the experimental and control groups.

$\mathrm{X}_{1}$ : Learning by using the blended learning model

$\mathrm{X}_{2}$ : Learning by using the model face to face (face to face learning). 
The study site is located at SMK Negeri 1 Kamal Bangkalan. This experiment was conducted in the even semester which was designed for 6 meetings (6 weeks) on 9 August to 5 September 2019. The population in this study was class XI all expertise competencies in SMK 1 Paringin which consisted of 4 classes with a total of 118 students. The composition of the number of classy students is as follows: (1) class XI KRA 30 students, (2) class XI KRB 27 students, (3) class XI AVI 27 students, and (4) class XI intrigue 34 students. All students in the four classes in principle have relatively the same basic computer skills. Determination of the control class and the experimental class was carried out by using techniques from the four classes that had been formed, while the remaining 2 classes were drawn again to determine the instrument trial class. Data collection instruments were a questionnaire sheet for students' motivation and a multiple choice test sheet for student achievement. Both instruments were given before and after learning in each sample group which took place 6 times. The data obtained were then analyzed and tested with parametric statistical f-tests, t-tests and univariate tests.

\section{Results and Discussion}

The following is a description of the research data for each group.

Table 3. Description of Control Class Research Data

\begin{tabular}{cccccc}
\hline & & Initial Motivation & Final Motivation & Pretest & Posttest \\
\cline { 3 - 5 }$N$ & 30 & 30 & 30 & 30 \\
\cline { 3 - 5 } Mean & 89,6667 & 89,7667 & 62,7633 & 72,8583 \\
Median & 90,5000 & 92,0000 & 62,8600 & 74,2900 \\
Mode & 93,00 & 92,00 & $54,29(\mathrm{a})$ & 8,29 \\
Std. Deviation & 5,86829 & 7,24775 & 10,10847 & 64,606 \\
Variance & 34,437 & 52,530 & 102,181 & 60,00 \\
Minimum & 71,00 & 72,00 & 48,57 & 88,57 \\
Maximum & 99,00 & 103,00 & 82,86 & \\
\hline
\end{tabular}

Table 4. Description of Experimental Class Research Data

\begin{tabular}{cccccc}
\hline \multirow{2}{*}{$\mathrm{N}$} & Valid & Initial Motivation & Final Motivation & Pretest & Posttest \\
\cline { 2 - 5 } & 30 & 30 & 30 & 30 \\
Mean & 96,7037 & 99,4047 & 62,0119 & 79,6848 \\
Median & 96,0000 & 99,0000 & 60,0000 & 80,0000 \\
Mode & 97,00 & 103,00 & $54,29(\mathrm{a})$ & 85,72 \\
Std. Deviation & 6,35982 & 7,36551 & 8,70922 & 8,01610 \\
Variance & 40,447 & 54,251 & 75,850 & 64,258 \\
Minimum & 84,00 & 83,00 & 45,72 & 62,86 \\
Maximum & 110,00 & 117,00 & 80,00 & 91,43 \\
\hline
\end{tabular}

Based on the results of normality and homogeneity tests, all data groups have been declared eligible.

Table 5. Test Requirements Analysis Results

\begin{tabular}{|c|c|c|}
\hline \multicolumn{3}{|c|}{ P Value for $a$} \\
\hline Data score & Normality test & Homogeneity test \\
\hline \multicolumn{3}{|c|}{ Group Control } \\
\hline Initial Motivation & $0,758>0,05-$ Normal & \\
\hline Final Motivation & $0,472>0,05-$ Normal & $0,166>0,05$ - Homogen \\
\hline Pretest & $0,560>0,05-$ Normal & \\
\hline Posttest & $0,696>0,05-$ Normal & $0,064>0,05-$ Homogen \\
\hline \multicolumn{3}{|c|}{ Experiment Control } \\
\hline Initial Motivation & $0,594>0,05-$ Normal & \multirow{2}{*}{$0,385>0,05-$ Homogen } \\
\hline Final Motivation & $0,990>0,05-$ Normal & \\
\hline Pretest & $0,605>0,05-$ Normal & \multirow{2}{*}{$0,912>0,05-$ Homogen } \\
\hline Posttest & $0,335>0,05-$ Normal & \\
\hline \multicolumn{3}{|c|}{ Gain Score } \\
\hline Motivation & $0,124>0,05-$ Normal & $0,201>0,05-$ Homogen \\
\hline Learning achievement & $0,377>0,05-$ Normal & $0,715>0,05-$ Homogen \\
\hline
\end{tabular}

Table 6. Output Anova Gain Skor Motivation

\begin{tabular}{cccccc}
\hline & Sum of Squares & Df & Mean Square & F & Sig. \\
\hline Between Groups & 96,377 & 1 & 96,337 & 4,211 & 0,045 \\
Within Groups & 1258,330 & 55 & 22,879 & & \\
Total & 1354,667 & 56 & & & \\
\hline
\end{tabular}

The results of the analysis in table 6 prove significantly that there are differences in students' motivation between learning with face to face learning compared with blended learning. This can be seen from the value of sig. output (P) 0.045 which is below 0.05 (a). 
Table 7. Output Paired Samples t-Test student's motivation to study

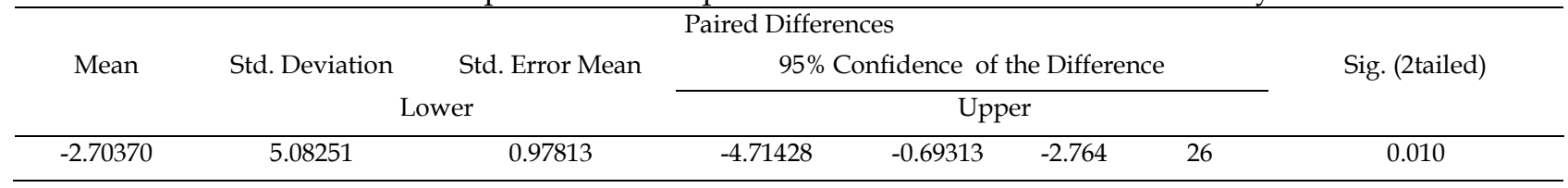

In table 7. it is proven that there is a significant increase in students' motivation in SMK 1 Kamal Bangkalan in KKPI subjects due to the application of the blended learning model. This can be seen from the value of sig. output (P) 0.010 which is below 0.05 ( $\alpha$ ).

Table 8. Average Students' motivation Learning Score

\begin{tabular}{cccccc}
\hline \multicolumn{2}{c}{$\begin{array}{c}\text { Face to face Learning (F2F) Model } \\
\text { Initial (A) }\end{array}$} & Final (B) & B - A & \multicolumn{2}{c}{ Blended Learning (BLEND) Model } \\
Initial (A) & 96,70 & Final (B) & B - A \\
\hline 89,67 & 89,77 & 0,10 & Increased motivation 2,7 point (2,8\%) & 2,70 \\
Increased motivation 0,10 point (0,11\%) & Increased motivation & BLEND Model for F2F 2,60 point (26x) \\
\hline \multicolumn{5}{c}{} \\
\hline
\end{tabular}

Based on table 8 and figure 1, it can be seen that the mean score of learning motivation of control class students increased by 0.10 points $(0.11 \%)$. Meanwhile the mean score of students' motivation in the experimental class increased 2.70 points $(2.8 \%)$. When compared to the increase in the average score of learning motivation of the two groups, the increase in learning motivation of experimental class students was 2.60 points (26-fold) compared to the increase in learning motivation scores of control class students.

\section{The Mean of Student Learning Motivation}

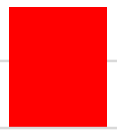

Initial

Face to Face Learning

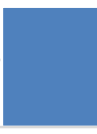

Final

Blended Learning

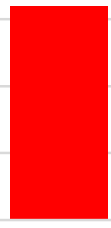

Initial

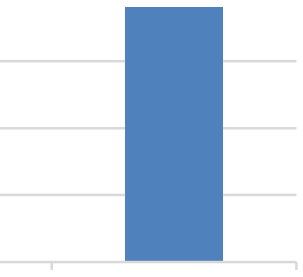

Final

Figure 1. Average Bar Chart of Student Learning Motivation

Table 9. Output Anova Gain Learning Achievement score

\begin{tabular}{cccccc}
\hline & Sum of Squares & Df & Mean Square & F & Sig. \\
\hline Between Groups & 816.047 & 1 & 816.047 & 8.311 & \\
Within Groups & 5400.212 & 55 & 98.186 & & \\
Total & 6216.259 & 56 & & & \\
\hline
\end{tabular}

The results of the analysis in table 9 prove significantly that there are differences in student achievement between learning with face to face learning compared to learning blended learning. This can be seen from the value of sig. output $(P) 0.006$ which is below $0.05(\mathrm{a})$.

Table 10. Output Paired Samples t-Test Student Achievement

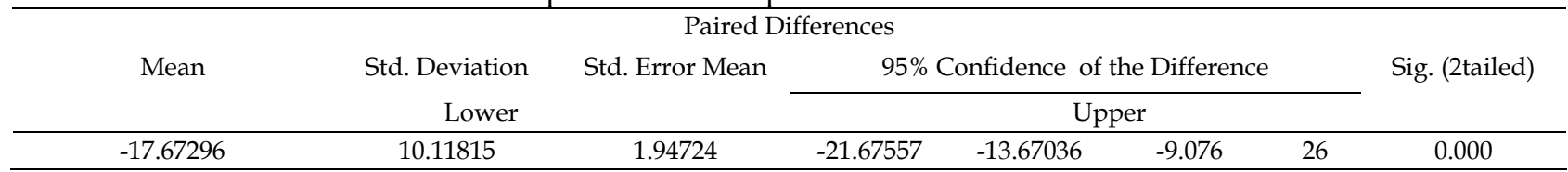

In addition, the results of the subsequent analysis in table 10, prove a significant increase in student achievement in Paringin Vocational High School 1 in KKPI subjects due to the application of the blended learning model. This can be seen from the value of sig. output (P) 0,000 which is below $0.05(\alpha)$.

Table 11. The Mean Score of Student Learning Achievement

\begin{tabular}{|c|c|c|c|c|c|}
\hline \multicolumn{3}{|c|}{ Face to face Learning (F2F) Model } & \multicolumn{3}{|c|}{ Blended Learning (BLEND) Model } \\
\hline Pretest (A) & Posttest (B) & $B-A$ & Pretest $(\mathrm{A})$ & Posttest (B) & B - A \\
\hline 62.76 & 72.86 & 10.10 & 62.01 & 79.68 & 17.67 \\
\hline \multicolumn{3}{|c|}{$\begin{array}{r}\text { Increased motivation } 0,10 \text { point }(0,11 \%) \\
\text { Increased motivat }\end{array}$} & Inc & vation 2,7 po & \\
\hline
\end{tabular}


The Mean of Student Learning Achievement

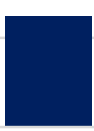

Pretest

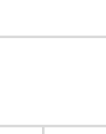

Posttest

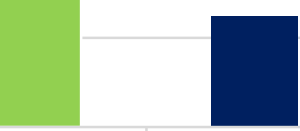

Pretest

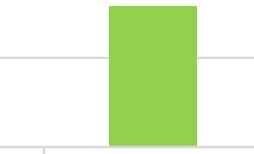

Posttest

Face to Face Learning

Blended Learning

Figure 2. Average Bar Chart of Student Learning Achievement

In table 11 and figure 2 shows an increase in student learning achievement in each group. The biggest increase occurred in the experimental class students. The mean score of students' achievement in control class increased significantly by 10.10 points (16\%). Meanwhile the mean score of students' achievement in experimental class increased significantly by 17.67 points $(28.5 \%)$. When compared to the two, the increase in learning achievement scores of experimental class students was 7.58 points $(75 \%)$ compared to the increase in learning achievement of control class students.

Blended learning model is able to dynamically shift the principle of learning from teacher center to student center. Model learning Blended learning is complementary to the lack of face-to-face learning and elearning models, because according to Munir (2009: 176) the weaknesses of e-learning include students physically and physically separated so that face-to-face interaction is reduced. Besides e-learning tends to be on training rather than education which leads to cognitive and psychomotor abilities and less attention to the affective aspects. Through face to face learning, teachers are able to function themselves as educators and provide direct and expressive motivational encouragement to students. Blended learning models make student activities in the classroom more varied. Students not only rely on information conveyed by the teacher, but try to get that information from various sources.

Table 12. Test of Between-Subjects Effects

\begin{tabular}{|c|c|c|c|c|c|c|}
\hline Source & $\begin{array}{c}\text { Type III Sum of } \\
\text { Squares }\end{array}$ & $\mathrm{df}$ & Mean Square & F & Sig. & $\begin{array}{c}\text { Partial Eta } \\
\text { Squared }\end{array}$ \\
\hline Corrected Model & 1043.148(a) & 3 & 347.716 & 3.562 & .0 .20 & .168 \\
\hline Intercept & 10878.780 & 1 & 10878.780 & 111.456 & .000 & .678 \\
\hline Motivation & 220.462 & 1 & 220.462 & 2.259 & 139 & .041 \\
\hline Model & 796.309 & 1 & 796.309 & 8.158 & .006 & 133 \\
\hline Motivation*Model & 11.321 & 1 & 11.321 & .116 & .735 & .002 \\
\hline Error & 5173.111 & 53 & 97.606 & & & \\
\hline Total & 16890.491 & 57 & & & & \\
\hline Corrected Total & 6216.259 & 56 & & & & \\
\hline
\end{tabular}

Subsequent analysis in Table 12 found no effect of interaction between learning models and students' motivation on learning achievement. Analysis too showed that in this study learning motivation did not significantly influence student achievement. Therefore the improvement in student learning achievement is really caused by application learning model type of blended learning.

Table 13. Descriptive Motivation *Learning Model Against Student Learning Achievement

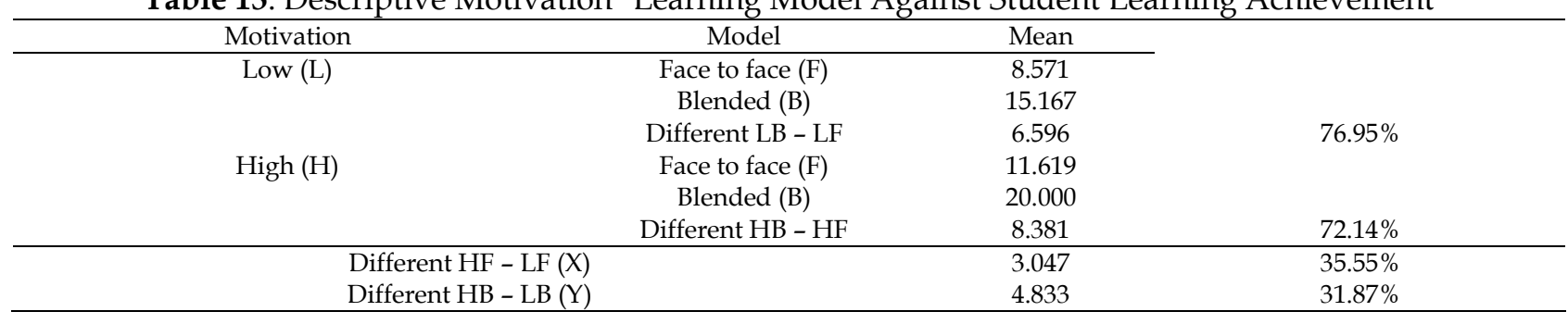

Based on table 13, it can be seen that the average number of learning achievements of the two groups of high and low motivated students is different. If it is explored further the average trend of student achievement in both high motivation groups and low motivation groups increases. There is a difference in the learning motivation of students with low motivation (LB-LF) from 8,571 to 15,167 (76.95\%). Meanwhile, there is a difference in the average motivation for learning achievement of highly motivated students (HB$\mathrm{HF}$ ) from 11,619 to $20,000(72.14 \%)$. In the same table, it was also found that the difference in learning motivation of students who were highly motivated towards students who were low motivated in face to face learning (HF-LF) was 3.047 points (35.55\%) and the difference in learning achievement of students who were highly motivated towards students who were highly motivated low motivation in learning blended learning (HB-LB) by 4.833 points $(31.87 \%)$ 
According to Sofyan and Uno (2004: 30) motive is a potential force for the occurrence of behavior or action. Figure 3 shows how the stimulus in the form of learning models has increased the motivation of the two groups to learn, but the motives of the two groups tend to produce relatively equal potential energy ( $\mathrm{HB}-\mathrm{HF}=72.14 \%$ and LB-LF $=76.95 \%$ ). Groups of students who are low motivated are not able to optimally respond to stimuli in the form of learning models in order to achieve the same or higher learning achievement than groups of students who are highly motivated. This is evident from the difference in learning achievement between the two groups in both treatments (X and Y). Based on attribution theory (Woolfolk, 2004: 354) there are 3 dimensions that influence the characteristics of attribution: (1) locus, (2) stability, and (3) controllability. The learning model applied to both classes is an external stimulus that is stable and the response produced is uncontrollable. Therefore learning motivation that is formed due to the influence of the application of the blended learning model does not significantly influence student learning achievement. Significant improvement in learning achievement is only due to the treatment given to students, namely the application of learning models.

In the control theory (cybernetics), it is explained how the individual exercises control over each stimulation he receives in accordance with the set point in himself (Hill, 2010: 268). Each stimulus is responded in accordance with the set point (set point) on each individual. Groups of students who are low motivated and groups of students who are highly motivated respond to stimuli in the form of learning models in their respective settings. Students who are highly motivated are familiar with learning activities and achievement motives so they tend to continue to maintain their position. Meanwhile students who are less motivated also behave in the same manner without any desire (set point) which is higher such as the desire to improve learning achievement than students who have better achievement. According to Wade \& Travis (2007: 190) achievement motivation will result in a maximum increase in learning achievement if students are able to combine the motivation formed both intrinsic and extrinsic due to the learning model with the ability to demonstrate the performance. Therefore the application of learning models that have a significant effect on increasing motivation to learn actually becomes the basis for further responses in the form of increased student achievement. But we need to realize that motivation is a complex psychological factor. According to Sofyan and Uno, the strongest motivation is intrinsic motivation compared to extrinsic motivation. In line with that, Woolfolk in educational psychology (2004: 352) states that the learning process must be able to create students 'intrinsic motivation by connecting students' interests and supporting the development of their competencies. In addition to applying the learning model to generate motivation externally, the teacher must strive to continue to develop intrinsic motivation because that motivation is able to provide the greatest impetus for the development of students' potential into an ability.

\section{Conclusion}

Based on the results of the study concluded as follows:

1. There are significant differences in learning motivation between classes that use the face to face learning model and classes that use the blended learning model.

2. There are significant differences in learning achievement between classes that use the face to face learning model and classes that use the blended learning model.

3. Student learning motivation increases significantly due to the application of the blended learning learning model.

4. Student learning achievement increases significantly due to the application of the blended learning learning model.

5. There is no interaction effect of the application of learning models and motivation on student achievement. Therefore the increase in student learning achievement is really significantly influenced by the application of the learning model.

\section{Acknowledgement}

The authors would like to thanks to the people who have been instrumental in their assistance and the successful completion of this study.

\section{Author's Contributions}

All authors discussed the results and contributed to from the start to final manuscript.

\section{Conflict of Interest}

The authors declare that they have no competing interests. 


\section{References}

Allen, IE, Seamen, J. \& Garret, R. (2007). Blending in: The extent and promise of blended education in the United States, USA: The Sloan Consortium.

Carman, J. M. (2005). Blended learning design: Five key ingredients, Download 20 November 2019, from http://www.agilantlearning.com-/pdf/Blend-ed\%20Learning\%-20Design.pdf.

Castle, S. R., \& McGuire, C. J. (2010). An analysis of student self-assessment of online, blended, and face-toface learning environments: Implications for sustainable education delivery. International Education Studies, 3(3), 36-40.

Chrisdian, V., Masitoh, S., \& Arianto, F. (2020). The Development of Mobile Learning Media for Excretion System Material for VIII Graders of SMPN 1 Taman Sidoarjo. International Journal for Educational and Vocational Studies, 1(8).

Clark, R.C., Mayer, R. E. (2008). e-Learning and the science of instruction, 2nd Ed, San Francisco: Pfeiffer.

Dachi, S. W., \& Batubara, I. H. (2020). The Development of Learning Model Through Problem Based Introduction (PBI) on Student's Motivation Improvement in Mathematics Education. International Journal for Educational and Vocational Studies, 2(2).

Daryanto. (2009). Panduan proses pembelajaran kreatif dan inovatif, Jakarta: AV Publisher.

Dorahman, B., Nuraeni, Y., Rosnaningsih, A., Sunaryo, S., \& Maulidyaputri, R. (2020). Developing Interactive Learning Media Based on Fowton. International Journal for Educational and Vocational Studies, $1(8)$.

Fadilla, N., Nurlaela, L., \& Maspiah, M. (2020). Application of Problem Based Learning Method in Entrepreneurship and Hygiene Sanitation with Flipped Classroom Strategy. International Journal for Educational and Vocational Studies, 1(8).

Mukodim, D. (2004). Peranan kesepian dan kecenderungan internet addiction disorder terhadap prestasi belajar mahasiswa Universitas Gunadarma. Proceedings, Komputer dan Sistem Intelejen (KOMMIT2004).

Halonen, J. S., \& Santrock, J. W. (1999). Psychology contexts \& applications. McGraw-Hill.

Hergenhahn, B. R., \& Olson, M. H. (2008). Theories of learning (Terjemahan Tri Wibowo), Jakarta: Kencana Prenada Media. Buku asli diterbitkan tahun.

Hill, W.F. (2010). Theories of learning, (Terje-mahan M. Khozim), Bandung: Nusa Media. (Buku asli diterbitkan tahun 1990).

Hutasuhut, J. (2019). Development of Scientific Learning System Based on Character Education (Honest, Discipline, Self-Confidence) in MTs-Al Maidah Deli Serdang Regency. International Journal for Educational and Vocational Studies, 1(7), 791-794.

Irfansyah, J., Ekohariadi, E., \& Buditjahjanto, A. (2020). The Effect of Using Augmented Reality Media in Learning Achievement Especially Psychomotor Domain at Computer Assembling Subject of $X$ Multimedia Students in SMKN 10 Surabaya. International Journal for Educational and Vocational Studies, 2(4).

Jamaludin, J., Eko, H., \& Arie, W. (2020). The Effect of Learning Habits and Learning Motivation on The Learning Achievement of The Workshop Theory in Aviation Politechnic Surabaya. International Journal for Educational and Vocational Studies, 2(2).

Jex, S.M. (2002). Organizational psychology: a scientist practitioner approach, New York: John Wiley \& Sons.

Johnson, R.L., Penny, J.A. \& Gordon, B. (2009). Assessing performance: designing, scoring, and validating performance tasks, New York: The Guilford Press.

Jusoff, K., \& Khodabandelou, R. (2009). Preliminary study on the role of social presence in blended learning environment in higher education. International Education Studies, 2(4), 79-83.

Munir, D., \& IT, M. (2009). Pembelajaran jarak jauh berbasis teknologi informasi dan komunikasi. Bandung: Alfabeta.

Mugaya, T. S. (2020). Using ICT to Improve Teaching and Learning of Kiswahili Language for University Students. International Journal for Educational and Vocational Studies, 2(4).

Nagara, K. B., Tola, B., \& Suprayati, Y. (2020). Evaluation of Thematic Integrative Learning Programs in Elementary School YPS Pertamina Prabumulih. International Journal for Educational and Vocational Studies, 2(2).

Naidu, S. (2006). E-learning: a guidebook of principles, procedures and practices. New Delhi: Aishi Creative Workshop.

Plummer, L. (2012). Credit recovery programs combine the best of online and in-class instruction. The Journal. 
Puspitasari, R., Miarsyah, M., \& Rusdi, R. (2020). Flash Based Interactive Multimedia Development to Increasing Learning Outcomes of Participants in High School in Materials Excretory System. International Journal for Educational and Vocational Studies, 2(4).

Rovai, A. P., \& Jordan, H. (2004). Blended learning and sense of community: A comparative analysis with traditional and fully online graduate courses. The International Review of Research in Open and Distributed Learning, 5(2).

Rahmi, A., Oktaviani, C., \& Alvina, S. (2020). Efforts To Improve Students' Multiple Intelligence In Dealing With Era 4.0 On The Subject of Basic Chemistry. International Journal for Educational and Vocational Studies, 2(1).

Sardiman, A. M. (1994). Interaksi dan motivasi belajar dan mengajar. Jakarta: Raja Grafindo Persada.

Sjahrir, A., Supardi, Z. A. I., \& Cahyaningrum, S. E. (2020). The Development and Validation of STEM-Based Learning Devices on Hydrostatic Pressure Material to Train Science Process Skills. International Journal for Educational and Vocational Studies, 2(2).

Siregar, A., Nurlela, L., Marniati, M., Rijanto, T., \& Munoto, M. (2020). The Application of Problem-Based Learning Method for Hygiene Sanitation Learning Eyes. International Journal for Educational and Vocational Studies, 2(2).

Slavin, R. E. (2009). Psikologi pendidikan: Teori dan praktik, (Terjemahan Marianto Samosir). Jakarta: Indeks. (Buku asli diterbitkan tahun 2006) Wade, C. \& Tavris, C. 2008. Psychology $9^{\text {th }}$ edition, Boston: Pearson Education.

Sofyan, H., \& Uno, H. B. (2004). Teori motivasi dan aplikasinya dalam penelitian. Jakarta: Nurul Jannah.

Woolfolk, A. (2004). Educational psychology. Boston: Pearson Education. Inc. 